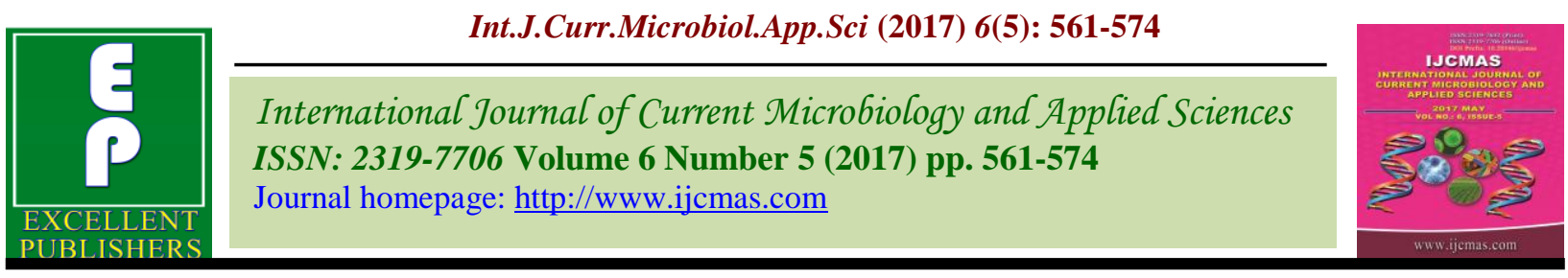

Original Research Article

https://doi.org/10.20546/ijcmas.2017.605.065

\title{
Effect of Storage Conditions on Product Characteristics and Microbiological Quality of Self Rising Flour
}

\author{
Tejinder Singh, Arashdeep Singh, Baljit Singh and Savita Sharma*
}

Department of Food Science and Technology, Punjab Agricultural University, Ludhiana, Punjab, 141004, India

*Corresponding author

\begin{tabular}{|c|c|}
\hline & B S T R A C T \\
\hline Keywords & \multirow{4}{*}{$\begin{array}{l}\text { The present investigation was therefore undertaken to examine the effect of storage } \\
\text { conditions (time, temperature and packaging material) of self rising flour containing } \\
\text { different leavening agents with acid calcium phosphate on the quality characteristics of } \\
\text { cookies, muffins and cakes and microbiological quality of self rising flour during storage. } \\
\text { Results showed that increase in the storage period of flour increased the top score, spread } \\
\text { ratio of cookies, specific volume, volume, evaluation scores and overall acceptability of } \\
\text { muffins and cakes as the cookies, muffins and cakes baked from fresh flour. Storage of } \\
\text { different combinations of flour at } 4{ }^{\circ} \mathrm{C} \text { results in superior quality of the bakery products } \\
\text { baked from such flour as compared to products baked from the flour stored at ambient } \\
\text { temperature. Cookies, muffin and cakes prepared flour packed in polyethylene bags shows } \\
\text { better top score, specific volume, evaluation score and overall acceptability scores as } \\
\text { compared to the products baked from the flour packed and stored in pearlpet jars. Increase } \\
\text { in the storage time increase the bacterial count and yeast and mold count in the flour } \\
\text { packed in polyethylene bags and pearlpet jars and stored at refrigeration temperature and } \\
\text { ambient temperature, however the microbial load remains in the prescribed limits. }\end{array}$} \\
\hline $\begin{array}{l}\text { Self rising flour, } \\
\text { cookies, muffins, }\end{array}$ & \\
\hline Article Info & \\
\hline $\begin{array}{l}\text { Accepted: } \\
\text { 04 April } 2017 \\
\text { Available Online: } \\
\text { 10 May } 2017\end{array}$ & \\
\hline
\end{tabular}

\section{Introduction}

Self rising flour was used to saves time and energy and also eliminates the hardships of measuring out the ingredient formulations. It helps to provide required quality of finished product. Self rising flour in general contains salt of different bicarbonate with an acid, which when dough and baked, release $\mathrm{CO} 2$ resulting in better dough aeration and development of good quality product (Singh et al., 2015). Fresh wheat flour presents a series of problems to the bakers. Aging refers to chemical and physical changes in wheat flour during storage, as newly milled wheat flour results in 'immature' dough which has poor mixing tolerance; gas withholding capabilities and yield undesirable bake loaf volume. Studies have shown that baking performance of flour can be improved to the optimum ageing of the flour and that quality can be maintained for a specific period of time, which could be deteriorated totally with prolonged storage (Fisher et al., 1937). The Young Flour quality was improved when stored for over a period of one month to two months, and this improvement was associated with substantially the storage temperature and other conditions storage (Ahmed, 2015). Protein, starch, and lipids present in the flour 
changes during storage directly affect the baking and rheological characteristics of the dough. Storage environment is very critical factor in flour aging as temperature, time, moisture, relative humidity $(\mathrm{RH})$, packaging material and microbial activity all affects the maturing of the flour (Wang and Flores, 1999). Flour aging is thought to occur naturally during storage of flour (MirandaGarcia, 2013), was thought to relate to oxidation of flour components including fatty acids and proteins (Cenkowski et al., 2000). Hrušková and Machová (2002) reported that storage time and conditions have an influence on the technological qualities of wheat flour and optimal maturation time depends on both the flour characteristics and storage conditions.

Cereal technologists commonly use empirical rheological and baking methods to predict end- product quality and these methods are often imitative of industrial processes and are rarely fundamental in nature (Miranda-Garcia, 2013). Studies reported that the baking qualities of wheat flour were substantially altered by the period and conditions of storage (Mis, 2003). Under optimum conditions of packaging and storage, the baking properties of flour was significantly improved improve. During storage water absorption of flour increases, which results in improving the rheological characteristics of dough and increase its ability to retain gas and produce bread with higher volume (Wang and Flores, 1999). These changes occur mainly due to the oxidation of the gluten proteins which is vital part of flour. During the storage of the flour content of the sulphydryl groups (-SH) decreased gradually which results in the construction of disulfide bonds (-S-S-) involving the polypeptide chains of gluten proteins which leads to enhance the degree of polymerization of the proteins (Yoneyama et al., 1970; Chen and Schofield 1996; Wrigley and Bekes, 1999). According to Mis (2003) knowledge of the influence of storage period on the rheological properties of gluten should be known to the professionals as it will directly affect the quality of dough and bread.

To the date dearth of literature is available on the effect of storage conditions of self rising flour on the quality characteristics of the products prepared from aged self rising flour. Hence the present investigation was undertaken to study the effect of storage time, temperature and packaging material of self rising flour on the quality characteristic of cookies, muffins and cakes and the microbiological quality of the flour during storage.

\section{Materials and Methods}

\section{Materials}

Commercial wheat flour, sodium and potassium bicarbonate, acid calcium phosphate was purchased from local market. Bakery shortening (Hydrogenated fat) having melting point of $37^{\circ} \mathrm{C}$, fresh ' $\mathrm{A}$ ' grade hen eggs, laboratory grade sodium chloride and ground table sugar for use in cookies, cakes and muffins was obtained from kipps grocery store, Ludhiana, Punjab. Skim milk powder was obtained from Verka Milk Plant, Ludhiana, Punjab. High density polyethylene (HDPE-250 gauge) and pearlpet jars were used for packaging of self rising flour. Packaging materials were obtained from local market.

\section{Preparation and storage self rising flour}

Ready to use self rising flour was prepared using different leavening agents (sodium bicarbonate and potassium in combination with acid calcium phosphate (ACP)) at recommended levels followed by thorough mixing. Different trails were conducted to standardize the level of leavening agents for 
self rising flour on the basis of final product quality. Self rising flour was prepared using following formulae after selecting the best leavening agent and its level from product quality score.

$\mathrm{NaHCO}_{3}(1.10 \%)+\mathrm{ACP}(1.4 \%)$

$\mathrm{NaHCO}_{3}: \mathrm{KHCO}_{3}(0.55 \%: 0.55 \%)+\mathrm{ACP}$ $(1.4 \%)$

$\mathrm{NaHCO}_{3}$ : Salt (1.10\%: 0.6\%) + ACP (1.4\%)

The flours so prepared were packaged in polyethylene bags and pearlpet jars and stored at ambient temperature $\left(30{ }^{\circ} \mathrm{C}\right)$ and refrigeration temperature $\left(4-5^{\circ} \mathrm{C}\right)$ for 3 months and it was evaluated from the quality characteristics of the prepared products.

\section{Methods}

\section{Product Preparation}

Cookies, muffins and cake were prepared in accordance with the standard procedures.. For cookies, flour and mixed with ingredients and kneeded to form dough which was then sheeted and cut into circular shapes and baked at $205{ }^{\circ} \mathrm{C}$. After baking, both cake and cookies were allowed to cool down at room temperature $\left(25 \pm 2^{\circ} \mathrm{C}\right)$ and then packed until used for evaluation. Bakery products i.e. muffins and cake was prepared in accordance with the standard procedures of AOAC 1990. For cake and muffins baking, fat and sugar was whipped in Horbart mixer at high speed for 4 min followed by addition of egg along with whipping for $1 \mathrm{~min}$. After that sieved flour and essence were added and contents were mixes at low speed. Batter in then poured into greased pan and baked at $400^{\circ} \mathrm{F}$ for $25 \mathrm{~min}$. After baking, the cake was cooled to ambient temperature $\left(25 \pm 2^{\circ} \mathrm{C}\right)$ and then packed in low density polyethylene until used for evaluation.

\section{Evaluation of product quality}

Top grain: Cookies were evaluated for their top grain score as per method of Vratanine and Zabik (1978)

W/T ratio: The thickness and width of six cookies was measures using standard procedure and then expressed as $\mathrm{W} / \mathrm{T}$ ratio.

Volume and specific volume: Muffins and Cakes prepared were analyzed for volume and specific volume respectively as per standard methods.

Overall acceptability: Prepared products were subjected to sensory evaluation by a panel of semi trained judges on a nine point hedonic scale and overall acceptability scores was recorded (Larmond, 1970).

\section{Microbiological analysis}

The microbiological quality of the fresh and stored flour samples was determined for total yeast and mold count and for psychotropic bacteria as per standard APHA (1992) procedures at regular interval during storage.

\section{Statistical analysis}

All the data was means of three observations. The data collected on different characteristics were analyzed statistically with the help of factorial design in CRD with one way ANOVA to assess whether each storage condition was significantly $(\mathrm{p}<0.05)$ different from the other condition.

\section{Results and Discussion}

Effect of storage conditions on the product characteristics of self rising flour containing $\mathrm{NaHCO}_{3}+\mathbf{1 . 4 \%}$ ACP

Cookies: Data for the effect of storage 
conditions of self rising flour containing $\mathrm{NaHCO}_{3}+1.4 \%$ ACP on the product characteristics of cookies, muffin and cake in presented in Table 1.

For cookies spread factor, sensory attributes and top score were significantly affected by storage conditions of self rising flour containing leavening agent sodium bicarbonate and ACP. Spread factor increased as duration of storage of self rising flour progressed. Significantly better spread factor (2.04) was obtained for self rising flour stored for 3 months as compared to fresh flour and one stored for one and two months which were 1.26, 1.27 and 2.0, respectively. The results of the effect of storage time on spread factor are in conformity with Sur et al., (1993).

Cookie top score which were characterized by extensive, symmetric and uniform cracks was influenced by storage period of flour. Cookies baked from fresh self rising flour had less uniform cracks with top score value 3.4. With increase in duration of storage uniformity and symmetry of cracks on cookie got improved. Maximum value of top score was observed after 3 months of storage (3.88). Similar trend was obtained for overall acceptability score which was mean value of colour, texture, taste and flavour scores. Overall acceptability score for cookies prepared from fresh flour was 7.30 , which increased significantly to 7.32 , 7.71 and 8.02 as duration of storage period progressed to 1, 2 and 3 months, respectively (Table 1). Cookies with good colour, taste, crispiness texture and pleasing flavour were obtained after 3 months of storage of flour contains sodium bicarbonate and ACP.

The cookie characteristics were also affected significantly with respect to storage temperature. The storage temperature produced notable effect in spread factor, top score and sensory characteristics.
Significantly higher spread factor was observed for cookies prepared from flour stored at refrigeration temperature in corresponding to ambient temperature stored flour (Table 1). Similarly, cookies with good surface characteristics were produced from flour stored at refrigeration temperature with top score value 3.79. Overall acceptability score was significantly greater for cookies prepared from flour stored at refrigeration temperature having overall acceptability score of 7.83 .

As illustrated in the Table 1, packaging material produced non-significant effect in spread ratio of cookies, but produced a significant variation in top score and overall acceptability. Cookies with extensive and uniform cracks were produced from flour stored in polyethylene bags. Similar interactions were observed for sensory attributes, which significantly greater values for cookies baked from flour had stored in polyethylene bags. The mean value of acceptability score for polyethylene bags store flour was 7.76, which significantly more than cookies prepared from flour contained in pearl pet jars.

\section{Muffins}

The data on Muffin making properties of the self rising flour having $\mathrm{NaHCO}_{3}+1.4 \%$ ACP as influenced by storage conditions is given in Table 1. Results showed that flour sample after 3 months of storage resulted into higher specific volume (1.17) of muffins as compared to the muffins baked form fresh flour sample (1.0). These values clearly depicts that there was significant improvement in muffin quality with aging of self rising flour. Internal scores as given by the panel of judges indicated that muffin prepared from flour stored for 3 months were better than as compared to the muffins baked form 1 and 2 month stored self rising flour. 
Similar trend was recorded for overall acceptability scores. Maximum value for acceptability score was obtained for muffins baked from flour that was stored for 3 months.

The values in the table for muffins with respect to the effect of storage temperature on muffin quality revealed that muffins prepared from self rising flour stored at refrigeration temperature were superior to that made from flour stored at ambient temperature. Specific volume (volume/weight) was significantly higher for muffins produced from flour sample kept at refrigeration temperature. The value of specific volume at refrigeration temperature was 1.11. Evaluation score (93.84) was significantly greater for muffins baked from refrigeration temperature stored flour. Similar trend was observed for all sensory attributes as higher acceptability score (8.28) was obtained for muffins which were prepared from flour kept at refrigeration temperature.

Effect of packaging material on the various properties of muffins from table values revealed that muffins produced from flour sample packaged in polyethylene bags had significantly better specific volume (1.10) as compared to that stored in pearl pet jars (1.06). Similar results were recorded with respect to evaluation score and more for muffins prepared from flour stored in polyethylene bags with value of 93.47. Colour, texture, taste, flavour scores also greater for muffins from polyethylene bags stored flour, which resulted into significant higher overall acceptability score (8.25) in corresponding to muffins baked from self rising flour stored in pearl pet jar (8.15).

\section{Cakes}

Data in Table 1 shows the effect of storage conditions of self rising flour containing sodium bicarbonate and ACP as leavening agent on cake making properties (volume, evaluation score and sensory attributes). Results showed that cake prepared from fresh self rising flour, had lower volume than those prepared from stored flour. Fresh flour baked cakes has volume of $680.0 \mathrm{cc}$. However with aging of flour volume of cakes got improved significantly and it increased to $687.0,690.63$ and $703.50 \mathrm{cc}$ after one, two and three months of storage respectively. Thus, this clearly depicted that cake volume gradually increased as the duration of storage increased. Based on the internal scores, cakes baked from fresh flour had significant different scores cakes baked from flour which was stored for three months. The mean values for visual evaluation score for fresh flour baked cakes were 91.0, which after 2 and 3 months of storage were increased to 95.25 and 95.75 , respectively. Similarly, overall acceptability scores of the cakes prepared from flour stored for 3 months were better than one prepared from fresh flour because of the higher value for colour, texture, taste and flavour scores. The results in the present study are in accordance with those earlier reported by Sur et al., (1993) for internal scores and sensory quality of cakes.

There was also a great variation noticed in overall quality of cakes prepared from flour samples stored at ambient and refrigeration temperature. Higher cake volume $(700.3 \mathrm{cc})$ was obtained from flour stored at refrigeration temperature as compared to ambient temperature. Visual evaluation score which include crumb and crust characteristics were also significantly superior for cakes baked from flour which was stored at low temperature. The sensory scores as given by the judges was also less for cakes corresponding to flour sample stored at ambient temperature while they were significantly higher (8.09) for cakes baked from flour stored at refrigeration temperature. 
Storage of flour in polyethylene bags and pearl pet jars also affected the overall quality of cake as inferred from the values presented in Table 1. The flour stored in polyethylene bags showed a significant greater cake volume (694.6cc) as compared to cake baked from flour stored in pearl pet jar $(685.9 \mathrm{cc})$. Cake prepared from flour packaged in polyethylene bags had significant higher internal score value (94.25) than that baked from flour stored in pearl pet jars (92.38) due to better crust and crumb quality. Similar interaction was also observed in case of sensory evaluation of product as overall acceptability value was greater (8.01) for cake baked from the flour stored in polyethylene (7.87) bags. Studies of Pomeranz (1971) reported that the bread-making quality of freshly milled wheat flour normally tends to improve with storage and it depending on the nature of the product and conditions of storage.

Effect of storage conditions of self rising flour containing $\mathrm{NaHCO}_{3}: \mathrm{KHCO}_{3}+1.4 \%$ $\mathrm{ACP}$ on the product characteristics

\section{Cookies}

Cookies baked from fresh and stored flour showed the significant differences for the quality characteristics. Table 2 depicts the effect of storage conditions of self rising flour containing sodium bicarbonate and potassium bicarbonate (50:50) in combination with ACP on cookie quality. As per data shown in the Table 2, overall quality of cookies was enhanced as the storage period of flour increased from 1 to 3 month. Spread factor of cookies increased significantly from 1.23 (for fresh flour) to 1.85 (cookies baked from flour stored for 3 months). In similar way, cookie cracks on top also improved in their uniformity with increase in the period of storage of self rising flour. The mean values of top score for fresh flour were 3.30, which increased significantly to $3.35,3.53$ and 3.68 after 1, 2 and 3 months of storage, respectively. Data for sensory evaluation of cookies showed that storage had significant influence on all the sensory attributes. The mean overall acceptability score for fresh flour was 7.07, while the cookies baked form the flour stored for three months were 7.72. Studies of Sur et al., (1993) earlier reported that of top score of cookies were higher of the samples baked from the flour stored for 45 days when compared with cookies baked from fresh flour.

Data presented in Table 2 also depicts the storage temperature has a significant effect on the cookie quality prepared from self rising flour stored at ambient and refrigeration temperature. Results showed that all cookie quality parameters were significantly improved for the flour stored at refrigeration temperature. The values of spread factor (1.56) and top score (3.64) were significantly more for cookies baked from 3 month stored flour as corresponds to self rising flour stored at refrigeration temperature. Similarly, acceptability score (7.58) was also significantly higher for the cookies baked from flour stores as low temperature as compared to cookies made from flour stored at ambient temperature (7.11). Wang and Flores (1999) in their review reported that milling and baking quality improved after newly harvested wheat was stored for several months.

Cookies prepared from flour sample stored in polyethylene bags had significantly higher value for top score and all sensory attributes, while spread ratio was not affected much packaging material. The value for spread ratio for cookies baked from flour packed in polyethylene bags was higher (1.55) than that made from the flour stored in pearlpet jar (1.53), however the effect was non significant. Similarly, top score values (3.53) was also higher for cookies prepared from flour stored in polyethylene as compared to 
pearl pet jar stored flour. All sensory attributes were greatly affected by type of packaging material. Acceptability score was higher for cookies baked from flour sample packaged in polyethylene bags while they significantly lower for the cookies baked from flour packed in pearl pet jars.

\section{Muffins}

Duration of storage period of self rising flour containing $\mathrm{NaHCO}_{3}: \mathrm{KHCO}_{3}+1.4 \%$ ACP significantly affected muffin's specific volume by increasing it from 0.99 for fresh flour to 1.05 after 3 months of storage, as depicted in Table 2. Increase in evaluation score was noticed for muffins with respect to increases in the duration of storage of flour. The value of evaluation score for fresh flour muffins was 90.0, where were significantly increased to 90.63 for muffins which were baked from flour which was aged for 3 months. As reflected from the values presented in Table 2, sensory acceptability of muffins was also improved with ageing of flour. Overall acceptability score for muffins baked from flour after 3 month storage time was significantly higher with value 8.12 as compared to fresh flour sample (7.83). Moss et al., (1991) studied the effects of age on the milling and baking quality of Australian wheat, and found no significant changes after 2 months of storage. However, bread scores improved slightly during aging of the wheat.

Storage temperature also significantly affected the quality self rising flour with respect to the product characteristics. Specific volume was significantly higher of muffins which were prepared from flour stored at refrigeration temperature with values of 1.03 while muffins baked from flour stored at ambient temperature has lower specific volume. Visual evaluation score followed the same trend. Significant higher evaluation score 90.78 was obtained for flour sample kept at low temperature. Low temperature stored flour showed better quality with respect to sensory attributes. Higher overall acceptability scores (8.10) was also achieved for muffins belonging to refrigeration temperature stored flour in comparison to ambient temperature stored flour.

Packaging material also played a significant role in affecting the quality of self rising flour during storage and the characteristics of the products prepared from such flour (Table 2). Specific volume of muffins was significantly better for flour stored in polyethylene bags as compared to flour stored in pearl pet jars. Similarly, evaluation score were (90.66) also better for polyethylene bags stored flour muffins but effect was non-significant. Sensory scores for all attributes as given by judges were higher for muffins baked from flour stored in polyethylene bags with acceptability score value 8.05 in comparison to muffins baked from the flour stored in pearl pet jars.

\section{Cakes}

Effect of storage time, temperature and packaging material on self rising flour was assessed by observing the quality of cake baked from resultant flour. Cakes baked from fresh self rising flour containing Sodium bicarbonate and potassium bicarbonate (0.55:0.55) in combination with $1.4 \%$ ACP had comparatively lower quality than cakes made from stored flour (Table 2). There was significant increase in all values of cake quality attributes during storage of self rising flour. Fresh flour sample gave the cake volume value of $677.0 \mathrm{cc}$ which significantly increased to $688.6 \mathrm{cc}$ for the flour storage for 3 months. Visual evaluation score was also maximum (92.88) at 3 months storage stage, which increased significantly from 89.0 for fresh flour. Sensory scores of colour, texture, taste, flavour as given by panel of semi trained judges were significantly higher for 
cakes prepared from stored flour sample as cake baled from 3 months stored flour contributed higher overall acceptability score for cakes (7.96) as compared to caked baked from fresh flour (7.73).

Storage temperatures for self rising flour also affected the quality of product. All quality parameters for cakes were momentously improved for samples prepared from flour stored at refrigeration temperature in comparison to cake baked from flour stored at ambient temperature. The values for cake volume, evaluation score and acceptability score were $693.7 \mathrm{cc}, 92.25$ and 7.93 respectively for the cake baked from flour sample stored at low temperature while the scores were $671.31,89.63$ and 7.72 for cake volume, evaluation score and acceptability score in caked baked from the sample stored at ambient temperature.

As inferred from the values given in Table 2, significant differences were observed in cake quality with respect to packaging material used for ageing and storage of self rising flour. Cake volume, internal scores and sensory scores were significantly higher for cakes baked from flour stored in polyethylene bags. Greater cake volume with value 685.8 cc was obtained from polyethylene bags packaged flour. Visual evaluation score (91.94) was also higher for cakes corresponding to self rising flour stored in low temperature. Similar trends were observed for the overall acceptability scores as caked baked from flour stored in polyethylene bags had overall acceptability score of 7.88 and for cakes made from flour sample stored in pearl pet jars the overall acceptability scores were 7.77. Similar results were obtained by Johnson and Hoseney (1980).

Effect of storage conditions of self rising flour containing $\mathrm{NaHCO}_{3}$ : Salt $(0.6 \%)+1.4 \%$ ACP on the product characteristics.

\section{Cookies}

Table 3 represents that all cookie characteristics were significantly improved during storage of self rising flour and they increased as the storage period increased from 1 to 3 months. Spread factor of cookies increased significantly to 1.76 at when prepared from the flour stored for 3 month which in the fresh flour was 1.18. Top score value increased from 2.50 (for fresh flour) to 2.93 (3 month aged flour). Sensory attribute score also increased significantly with increase in the storage period of self rising flour containing salt. The value of overall acceptability score for the cookies baked from 3 months stored flour was 6.94 which was 6.50 for the cookies made from fresh flour. Cookie quality was significantly better when prepared from flour stored low temperature as compared to flour stored at ambient temperature. The values for spread factor, top score and overall acceptability score were $1.49,2.94$ and 6.87, for the cookies prepared from low temperature stored flour as corresponding to spread factor, top score and overall acceptability score of 1.46, 2.49 and 6.64 cookies prepared from flour sample stored at ambient temperature.

Effect of packaging material during storage of self rising flour containing salt with respect to product quality also depicted in Table 3 showed that packaging material used for ageing of self rising flour significantly affects the characteristics of the cookies prepared from such flour. Quality of self rising flour containing sodium bicarbonate $(1.10 \%)$ and salt $(0.6 \%)$ plus ACP $(1.4 \%)$ stored in polyethylene bags was comparatively better than that packaged in pearlpet jars. Cracks on top were better for cookies baked from sample taken from flour stored in polyethylene bags with top score value 2.80 . Similarly, acceptability value (6.83) was significantly higher for polyethylene bags stored flour cookies. 
Studies of Aboubakar et al., (2010) reported that storage period of flour should not exceed 3 month for and to keep good physicochemical and rheological parameters, flours should be stored in a sealed polyethylene bag.

\section{Muffins}

Quality of self rising flour was improved significantly during three month of storage as inferred from the better quality characteristic of the product prepared from the aged flour in comparison to fresh flour. As illustrated in Table 3 specific volume of muffins at prepared from flour stored for 3 month of was significantly increased to 1.0 , as the muffins baked from fresh flour had low specific volume (0.86). Internal scores for muffins prepared from fresh flour were 86.0, this score significantly increased to 87.63 in the cookies prepared from 3 month stored of flour. Same pattern was followed by sensory scores of the muffins as the overall acceptability score for muffins baked from fresh flour was 7.57 which were increased to 7.83 after 1 moth of ageing and further increased to 7.88 and 7.92at after $2^{\text {nd }}$ and $3^{\text {rd }}$ month of storage.

Overall quality of muffins produced from self rising flour stored at refrigeration temperature was significantly better. The values for specific volume (0.95), evaluation score (87.75) and acceptability score (7.90) were significantly higher for muffins prepared from flour stored at refrigeration temperature as compared to the muffins baked from the flour stored at ambient temperature which has lower specific volume (0.93), evaluation score (86.19) and acceptability score (7.70).

Effect of packaging material on quality of self rising flour concluded that self rising flour quality stored in polyethylene bags was better as compared to that stored in pearlpet jars. Muffins baked from the flour stored in polyethylene bags has significantly better specific volume, evaluation score (based on crumb and crust characteristics) and overall acceptability scores in comparison to the muffins baked from the flour packed and aged in pearlpet jars, data for which was shown in Table 3.

\section{Cake}

Volume of cakes made from fresh self rising flour was $670 \mathrm{cc}$ which significantly increased to $680.1 \mathrm{cc}$ the cake prepared from 3 month storage flour (Table 3). Visual evaluation score was also maximum (86.13) for the caked baked from the flour aged for 3 months as compared to cake prepared from fresh flour (80.00) and flour aged for 1 (84.50) and 2 months (85.75). Data shows that as the ageing period increased the values and scores for the quality characteristics of the product also increased. Colour, texture, taste and flavour scores were increased up to 3 months of storage and hence, the overall acceptability score (7.50) reported by judges was better for cakes baked from aged flour than the cakes baked from fresh flour (6.53).

Storage temperature also has a significant effect on the quality characteristics of the cakes baked from self rising flour as low temperature storage resulted in better baking quality which was inferred from higher acceptability score values (Table 3). The values overall acceptability scores for cakes baked from the flour stored at ambient and refrigeration temperatures were 6.91 and 7.23 respectively. However, packaging material did not affect the cake quality to much extent. The values for quality parameters were at par when the flour stored in polyethylene bags and pearlpet jars. 
Int.J.Curr.Microbiol.App.Sci (2017) 6(5): 561-574

Table.1 Effect of storage conditions of self rising flour containing NaHCO3 (1.10\%) + ACP (1.4\%) on bakery product quality

\begin{tabular}{|c|c|c|c|c|c|c|c|c|c|}
\hline \multirow[b]{2}{*}{ Storage Conditions } & \multicolumn{3}{|c|}{ Cookies } & \multirow{2}{*}{$\begin{array}{c}\text { Muffins } \\
\text { Specific } \\
\text { Volume }\end{array}$} & \multicolumn{5}{|c|}{ Cakes } \\
\hline & $\mathbf{W} / \mathbf{T}$ & $\begin{array}{c}\text { Top } \\
\text { Score* }\end{array}$ & $\begin{array}{c}\text { Overall } \\
\text { Acceptabilit } \\
\mathbf{y}^{\#} \\
\end{array}$ & & $\begin{array}{l}\text { Evaluatio } \\
\text { n Score }{ }^{* *}\end{array}$ & $\begin{array}{l}\text { Overall } \\
\text { Acceptability }^{\#}\end{array}$ & $\begin{array}{l}\text { Volume } \\
\text { (cc) }\end{array}$ & $\begin{array}{c}\text { Evaluation } \\
\text { Score }^{* *}\end{array}$ & $\begin{array}{c}\text { Overall } \\
\text { Acceptabilit } \\
\mathbf{y}^{\#} \\
\end{array}$ \\
\hline \multicolumn{10}{|l|}{ Time (months) } \\
\hline 0 & 1.26 & 3.40 & 7.30 & 1.00 & 90.00 & 1.00 & 680.0 & 91.00 & 7.78 \\
\hline 1 & 1.27 & 3.50 & 7.32 & 1.00 & 91.88 & 1.00 & 687.0 & 91.25 & 7.84 \\
\hline 2 & 2.00 & 3.88 & 7.71 & 1.16 & 93.25 & 1.16 & 690.6 & 95.25 & 8.01 \\
\hline 3 & 2.04 & 3.88 & 8.02 & 1.17 & 95.10 & 1.17 & 703.5 & 95.75 & 8.14 \\
\hline \multicolumn{10}{|l|}{ Temperature } \\
\hline Ambient Temperature & 1.60 & 3.54 & 7.34 & 1.05 & 91.25 & 1.05 & 680.25 & 92.19 & 7.80 \\
\hline $\begin{array}{l}\text { Refrigeration } \\
\text { Temperature }\end{array}$ & 1.69 & 3.79 & 7.83 & 1.11 & 93.84 & 1.11 & 700.31 & 94.44 & 8.09 \\
\hline \multicolumn{10}{|l|}{ Packaging Material(PM) } \\
\hline HDPE Bags & 1.67 & 3.79 & 7.76 & 1.10 & 93.5 & 1.10 & 694.63 & 94.25 & 8.01 \\
\hline Pearlpet Jar & 1.62 & 3.54 & 7.40 & 1.06 & 91.6 & 1.06 & 685.94 & 92.38 & 7.87 \\
\hline \multicolumn{10}{|l|}{$\mathbf{C D}(p>0.05)$} \\
\hline Storage Time & 0.075 & 0.30 & 0.073 & 0.013 & 1.26 & 0.013 & 1.43 & 0.82 & 0.056 \\
\hline Temperature & 0.053 & 0.22 & 0.052 & 0.009 & 0.89 & 0.009 & 1.01 & 0.58 & 0.040 \\
\hline PM & NS & 0.22 & 0.052 & 0.009 & 0.89 & 0.009 & 1.01 & 0.58 & 0.040 \\
\hline
\end{tabular}

${ }^{\#}$ Score out of $9.0,{ }^{*}$ Score out of $4.0, * *$ Score out of 100, HDPE: High Density Polyethylene 
Table.2 Effect of storage conditions of self rising flour containing NaHCO3:KHCO3 (0.55:0.55) + ACP (1.4\%) on bakery product quality

\begin{tabular}{|c|c|c|c|c|c|c|c|c|c|}
\hline \multirow[b]{2}{*}{ Storage Conditions } & \multicolumn{3}{|c|}{ Cookies } & \multirow{2}{*}{$\begin{array}{c}\text { Muffins } \\
\text { Specific } \\
\text { Volume }\end{array}$} & \multicolumn{5}{|c|}{ Cakes } \\
\hline & $\begin{array}{l}\mathbf{W} / \\
\mathbf{T}\end{array}$ & $\begin{array}{c}\text { Top } \\
\text { Score }^{*}\end{array}$ & $\begin{array}{c}\text { Overall } \\
\text { Acceptabilit } \\
\mathbf{y}^{\#} \\
\end{array}$ & & $\begin{array}{l}\text { Evaluatio } \\
\text { n Score }{ }^{* *}\end{array}$ & $\begin{array}{l}\text { Overall } \\
\text { Acceptabilit } \\
y^{\#}\end{array}$ & $\begin{array}{l}\text { Volume } \\
\text { (cc) }\end{array}$ & $\begin{array}{c}\text { Evaluation } \\
\text { Score }^{* *}\end{array}$ & $\begin{array}{c}\text { Overall } \\
\text { Acceptability }\end{array}$ \\
\hline \multicolumn{10}{|l|}{ Time (months) } \\
\hline 0 & 1.23 & 3.30 & 7.07 & 0.99 & 90.00 & 7.83 & 677.00 & 89.00 & 7.73 \\
\hline 1 & 1.24 & 3.35 & 7.19 & 1.00 & 90.13 & 8.02 & 679.75 & 89.50 & 7.78 \\
\hline 2 & 1.84 & 3.53 & 7.42 & 1.05 & 90.56 & 8.06 & 684.75 & 92.38 & 7.85 \\
\hline 3 & 1.85 & 3.68 & 7.72 & 1.05 & 90.63 & 8.12 & 688.63 & 92.88 & 7.96 \\
\hline \multicolumn{10}{|l|}{ Temperature } \\
\hline Ambient Temperature & 1.52 & 3.29 & 7.11 & 1.01 & 89.88 & 7.91 & 671.31 & 89.63 & 7.72 \\
\hline $\begin{array}{l}\text { Refrigeration } \\
\text { Temperature }\end{array}$ & 1.56 & 3.64 & 7.58 & 1.03 & 90.78 & 8.10 & 693.76 & 92.25 & 7.93 \\
\hline \multicolumn{10}{|l|}{ Packaging Material(PM) } \\
\hline HDPE Bags & 1.55 & 3.53 & 7.48 & 1.03 & 90.66 & 8.05 & 685.81 & 91.94 & 7.88 \\
\hline Pearlpet Jar & 1.53 & 3.40 & 7.21 & 1.02 & 90.00 & 7.96 & 679.25 & 89.94 & 7.77 \\
\hline $\mathbf{C D}(\mathrm{p}>0.05)$ & & & & & & & & & \\
\hline Storage Time & 0.029 & 0.13 & 0.065 & 0.013 & NS & 0.055 & 1.43 & 1.18 & 0.036 \\
\hline Temperature & 0.021 & 0.095 & 0.046 & 0.009 & 0.79 & 0.039 & 1.01 & 0.84 & 0.026 \\
\hline PM & NS & 0.095 & 0.046 & 0.009 & NS & 0.039 & 1.01 & 0.84 & 0.026 \\
\hline
\end{tabular}

\# Score out of 9.0, *Score out of 4.0, ** Score out of 100, HDPE: High Density Polyethylene 
Table.3 Effect of storage conditions of self rising flour containing NaHCO3 $(1.10 \%)+$ ACP $(1.4 \%)+$ Salt $(0.6 \%)$ on bakery product quality

\begin{tabular}{|c|c|c|c|c|c|c|c|c|c|}
\hline \multirow[b]{2}{*}{$\begin{array}{c}\text { Storage } \\
\text { Conditions }\end{array}$} & \multicolumn{3}{|c|}{ Cookies } & \multirow{2}{*}{$\begin{array}{c}\text { Muffins } \\
\text { Specific } \\
\text { Volume }\end{array}$} & \multirow[b]{2}{*}{$\begin{array}{c}\text { Evaluation } \\
\text { Score** }\end{array}$} & \multicolumn{2}{|c|}{ Cakes } & \multirow[b]{2}{*}{$\begin{array}{c}\text { Evaluation } \\
\text { Score** }\end{array}$} & \multirow[b]{2}{*}{$\begin{array}{c}\text { Overall } \\
\text { Acceptability }\end{array}$} \\
\hline & $\mathbf{W} / \mathbf{T}$ & $\begin{array}{c}\text { Top } \\
\text { Score* }\end{array}$ & $\begin{array}{c}\text { Overall } \\
\text { Acceptability }^{\#}\end{array}$ & & & $\begin{array}{l}\text { Overall } \\
\text { Acceptability }\end{array}$ & $\begin{array}{c}\text { Volume } \\
\text { (cc) }\end{array}$ & & \\
\hline \multicolumn{10}{|l|}{ Time (months) } \\
\hline 0 & 1.18 & 2.50 & 6.50 & 0.86 & 86.00 & 7.57 & 670.0 & 80.00 & 6.53 \\
\hline 1 & 1.20 & 2.58 & 6.65 & 0.90 & 87.00 & 7.83 & 675.0 & 84.50 & 6.76 \\
\hline 2 & 1.76 & 2.88 & 6.92 & 1.00 & 87.25 & 7.88 & 679.4 & 85.75 & 7.48 \\
\hline 3 & 1.76 & 2.93 & 6.94 & 1.00 & 87.63 & 7.92 & 680.1 & 86.13 & 7.50 \\
\hline \multicolumn{10}{|l|}{ Temperature } \\
\hline Ambient temperature & 1.46 & 2.49 & 6.64 & 0.93 & 86.19 & 7.70 & 648.94 & 83.44 & 6.91 \\
\hline Refrigeration temperature & 1.49 & 2.94 & 6.87 & 0.95 & 87.75 & 7.90 & 656.38 & 84.75 & 7.23 \\
\hline \multicolumn{10}{|l|}{ Packaging Material (PM) } \\
\hline HDPE Bags & 1.48 & 2.80 & 6.83 & 0.95 & 87.38 & 7.85 & 654.19 & 84.38 & 7.12 \\
\hline Pearlpet Jar & 1.47 & 2.64 & 6.67 & 0.93 & 86.56 & 7.75 & 651.13 & 83.81 & 7.01 \\
\hline \multicolumn{10}{|l|}{$\mathbf{C D}(p>0.05)$} \\
\hline Storage Time & 0.016 & 0.074 & 0.084 & 0.018 & NS & 0.042 & 1.43 & 1.17 & 0.038 \\
\hline Temperature & 0.011 & 0.052 & 0.059 & 0.013 & 0.91 & 0.030 & 1.01 & 0.83 & 0.027 \\
\hline PM & NS & 0.052 & 0.059 & 0.013 & NS & 0.030 & 1.01 & NS & 0.027 \\
\hline
\end{tabular}

${ }^{\#}$ Score out of 9.0, *Score out of 4.0,** Score out of 100, HDPE: High Density Polyethylene

Table.4 Effect of storage condition on the microbiological quality of the self rising flour

\begin{tabular}{|c|c|c|c|c|c|c|c|c|}
\hline \multirow{3}{*}{$\begin{array}{l}\text { Storage time } \\
\text { (months) }\end{array}$} & \multicolumn{4}{|c|}{ Bacterial count (cfu/gm) } & \multicolumn{4}{|c|}{ Yeast and mold count (cfu/gm) } \\
\hline & \multicolumn{2}{|c|}{ AT } & \multicolumn{2}{|c|}{ RT } & \multicolumn{2}{|c|}{ AT } & \multicolumn{2}{|c|}{ RT } \\
\hline & HDPE & PJ & HDPE & $\mathbf{P J}$ & HDPE & PJ & HDPE & PJ \\
\hline 0 & \multicolumn{4}{|c|}{$7 \times 10^{2}$} & \multicolumn{4}{|c|}{$10 \times 10^{3}$} \\
\hline 1 & $10 \times 10^{2}$ & $11 \times 10^{2}$ & $11 \times 10^{2}$ & $10 \times 10^{2}$ & $3 \times 10^{3}$ & $4 \times 10^{3}$ & $2 \times 10^{3}$ & $2 \times 10^{3}$ \\
\hline 2 & $20 \times 10^{2}$ & $22 \times 10^{2}$ & $23 \times 10^{2}$ & $25 \times 10^{2}$ & $12 \times 10^{3}$ & $12 \times 10^{3}$ & $9 \times 10^{3}$ & $10 \times 10^{3}$ \\
\hline 3 & $150 \times 10^{2}$ & $155 \times 10^{2}$ & $100 \times 10^{2}$ & $105 \times 10^{2}$ & $20 \times 10^{3}$ & $24 \times 10^{3}$ & $28 \times 10^{3}$ & $30 \times 10^{3}$ \\
\hline
\end{tabular}


According to McCalla et al., (1939) the bread-making value of long patent hard wheat flour stored in sealed containers at $13.5 \%$ moisture and 16 to $28{ }^{\circ} \mathrm{C}$ fell off quite markedly within 3 months, but when stored in bags the flour improved for 6 months.

\section{Effect of storage conditions of self rising flour on the microbiological quality}

Data in Table 4 depicts the microbiological quality of the self rising flour as influenced by storage conditions. The flour has restricted water activity $\left(a_{w}\right)$, so the micro flora should remain constant in different storage conditions (ambient temperature, refrigeration temperature and polyethylene bags, pearlpet jars). In patent flour the count is usually within the range of $10^{2}$ to $10^{4}$ per germ and the number decrease during storage of flour. In present studies in the fresh flour the yeast and mold count $\left(10 \times 10^{3} \mathrm{cfu} / \mathrm{g}\right)$ and bacterial load $\left(7 \times 10^{2} \mathrm{cfu} / \mathrm{g}\right)$ observed was within the permissible range and varied slightly with storage conditions. The count in our case was constant as the storage conditions did not varies much. After one month of storage the bacterial count of self rising flour in polyethylene bags at ambient temperature was $10 \times 10^{2} \mathrm{cfu} / \mathrm{g}$, pearlpet jars was $11 \times 10^{2}$ $\mathrm{cfu} / \mathrm{g}$. Similarly flour stored at refrigeration temperature and packaged in polyethylene bags and pearlpet jars had bacterial count $11 \mathrm{x}$ $10^{2} \mathrm{cfu} / \mathrm{g}$ and $10 \times 10^{2} \mathrm{cfu} / \mathrm{g}$, respectively. While yeast and mold count for flour stored at ambient temperature and refrigeration temperature had $\left(3 \times 10^{3} \mathrm{cfu} / \mathrm{gm}\right.$ and $4 \times 10^{3}$ $\mathrm{cfu} / \mathrm{g}$ ) for polyethylene bags and pearlpet jars stored flour respectively and $2 \times 10^{3} \mathrm{cfu} / \mathrm{g}$ for both packaging material, respectively. After two months of storage of flour the bacterial count, yeast and mold count for flour stored at ambient temperature and packaged in polyethylene bags and peralpet jars were $20 \mathrm{x}$ $10^{2}, 22 \times 10^{2}$ and $12 \times 10^{3}, 12 \times 10^{3} \mathrm{cfu} / \mathrm{gm}$, respectively. Similarly these counts for flour stored at refrigeration temperature for 60 days and packaged in same packaging materials were $23 \times 10^{2} \mathrm{cfu} / \mathrm{g}, 25 \times 10^{2} \mathrm{cfu} / \mathrm{g}$ and $9 \times$ $10^{3} \mathrm{cfu} / \mathrm{g}, 10 \times 10^{3} \mathrm{cfu} / \mathrm{g}$, respectively. Bacterial and yeast mold count of self rising flour after 3 month storage is given in Table 4. Bacterial and yeast, mold count for flour stored at ambient temperature and packaged in polyethylene bags and pearlpet jars were $150 \times 10^{2} \mathrm{cfu} / \mathrm{g}, 155 \times 10^{2} \mathrm{cfu} / \mathrm{g}$ and $20 \times 10^{3}$ $\mathrm{cfu} / \mathrm{g}, 24 \times 10^{3} \mathrm{cfu} / \mathrm{g}$, respectively. While these counts for flour stored at refrigeration temperature and packaged in polyethylene bags and pearlpet jars were $100 \times 10^{2} \mathrm{cfu} / \mathrm{g}$, $105 \times 10^{2} \mathrm{cfu} / \mathrm{g}$ and $28 \times 10^{3}, 30 \times 10^{3} \mathrm{cfu} / \mathrm{g}$ respectively after 90 days. Therefore, microbiological experiment interpreted that the self rising flour stored in polyethylene bags and pearlpet jars at ambient temperature and refrigeration temperature for 3 months had better suitability as the count (microbial load) remained within the permissible limits.

In conclusion, the study revealed that storage condition significantly influenced the quality characteristics of the bakery products prepared from the self rising flour. The self rising flour containing different leavening agents along with acid calcium phosphate produce high quality cookies, muffins and cakes after 3 months of storage as compared to fresh flour and flour stored for 1 and 2 months. The top score, spread ratio, specific volume and overall acceptability scores were higher for the products baked from flour which was packed in polyethylene bags and stored at refrigeration temperature. The microbiological quality of the flour also remained within the permissible limits during 3 months storage. Hence, self rising flour can be aged for three months at low temperature for preparation of cookies having extensive, symmetric and uniform cracks, muffins and cakes with higher specific volume and superior overall acceptability. 


\section{References}

Aboubakar., Njintang, Y.N., Nguimbou, R.M., Scher, J. and Mbofung, C.M. 2010. Effect of storage on the physicochemical, functional and rheological properties of taro flour and paste. Innov. Romanian Food Biotechnol., 7: 37-48.

Ahmed, M.S.H. 2015. Effect of storage temperature and periods on some characteristics of wheat flour quality. Food Nutr. Sci., 6: 1148-1159.

AOAC. 1990. Official methods of analysis, Association of official analytical Chemists, St. Paul, Minn, USA.

APHA. 1992. Compendium of Methods for the microbiological examination of foods. $3^{\text {rd }}$ Edition, American Public Health Association, Washington, D.C.

Cenkowski, S., Dexter, J.E. and Scanlon, M.G. 2000. Mechanical compaction of flour: the effect of storage temperature on dough rheological properties. Canadian Agric. Engg., 42: 33-41.

Chen, X. and Schofield, J.D. 1996. Changes in the glutathione content and breadmaking performance of white wheat flour during short-term storage. Cereal Chem., 73: 1-4.

Fisher, E.A., Halton, P. and Carter, R.H. 1937. Studies on the storage of wheaten flour. I. Effect of storage on the chemical composition and baking quality of flour. Cereal Chem., 14: 135.

Hrušková, M. and Machová, D. 2002. Changes of Wheat Properties during Short Term Storage. Czech J. Food Sci., 20: 125-130.

Johnson, A.C. and Hoseney, R.C. 1980. Chlorine treatment of cake flour IV. Effects of storing and heating non-defatted and defatted flours. Cereal Chem., 57: 92.

Larmond, E. 1970. Methods of Sensory
Evaluation of Food. Can. Dept. Agric., 1284.

Miranda-Garcia, O. 2013. The storage of grain and aging of flour, and their effects on flour functionality. Undergraduate Thesis, Oregon State University.

Mis, A. 2003. Influence of the storage of wheat flour on the physical properties of gluten. Intl. Agrophysics, 17: 71-75

Moss, R., Reid, A. and Stephenson, J. 1991. An overview of the Australian milling industry and research carried out on the Bread Research Institute pilot mill. Assoc. Oper. Millers Bull., 5923-5930.

Pomeranz, Y. 1971. Biochemical and functional changes in stored cereal grains. Critical Rev. Food Technol., 4: 45.

Sur, R., Nagi, H.P.S., Sharma, S. and Sekhon, K.S. 1993. Storage changes in the quality of sound and sprouted flour. Plant Foods Human Nutr., 44: 35-44.

Tejinder, S., Bobade, H., Savita, S. and Baljit, S. 2015. Formulation and standardization of self rising flour as a convenience food article for preparation of high quality cookies. Res. J. Agric. Forestry Sci., 3: 5-9.

Vratanine, D.L. and Zabik, M.E.1978. Dietary fiber sources for baked products: Bran in sugar-snap cookies, J. Food Sci., 43: 1590.

Wang, L.F. and Flores, R.A. 1999. The effect of storage on flour quality and baking performance. Food Rev. Intl., 15: 215-234.

Wrigley C.W. and Bekes F. 1999. Gluteninprotein formation during the continuum from anthesis to processing. Cereal Foods World, 44: 562-565.

Yoneyama, T., Suzuki, I. and Murohashi, M. 1970. Natural maturing of wheat flour. I. Changes in some components and in Farinograph and Extensigraph properties. Cereal Chem., 47: 19-26.

\section{How to cite this article:}

Tejinder Singh, Arashdeep Singh, Baljit Singh and Savita Sharma. 2017. Effect of Storage Conditions on Product Characteristics and Microbiological Quality of Self Rising Flour. Int.J.Curr.Microbiol.App.Sci. 6(5): 561-574. doi: https://doi.org/10.20546/ijcmas.2017.605.065 